This PDF is a selection from a published volume from the National Bureau of Economic Research

Volume Title: NBER International Seminar on Macroeconomics 2008

Volume Author/Editor: Jeffrey Frankel and Christopher Pissarides

Volume Publisher: University of Chicago Press

Volume ISBN: 978-0-226-10732-5

Volume URL: http://www.nber.org/books/fran08-1

Conference Date: June 20-21, 2008

Publication Date: April 2009

Title: Introduction to "NBER International Seminar on Macroeconomics 2008"

Author: Jeffrey Frankel, Christopher Pissarides

URL: http://www.nber.org/chapters/c8228

Chapter pages in book: (1 - 5) 


\title{
Introduction
}

\author{
Jeffrey Frankel and Christopher Pissarides
}

The International Seminar on Macroeconomics (ISOM) meets every June in a different European city, bringing together American and European economists to study a variety of topics within "macroeconomics" defined very broadly. NBER's thirty-first International Seminar on Macroeconomics took place on June 20 and 21, 2008. This was the thirtieth anniversary of the first ISOM meeting (which took place in Paris in 1978), one of the many innovations made by Martin Feldstein when he became president of the NBER. Jeffrey Frankel is now overall codirector of ISOM on behalf of the NBER, with Francesco Giavazzi as his European counterpart.

We continue to work with a local host in a different European country each summer and to divide the authors and discussants equally between Americans and Europeans. Geographically, ISOM has been venturing farther afield than its origins in the major countries of western Europe. Since 2005 we have often held meetings in central Europe, among countries that have recently acceded, or hope to accede, to the European Union. Our 2008 host country, Slovenia, had just joined the euro the year beforethe first of the transition economies to do so.

Frankel and Christopher Pissarides organized this year's program. The papers published here have gone through a rigorous refereeing process, chiefly by the ISOM board. The University of Chicago Press Journals Division publishes them as a companion volume to the NBER Macroeconomics Annual.

\section{Overview of the Volume}

The seven papers published in the thirty-first volume of ISOM, as usual, cover quite a range of topics. While the subject matter of the papers ranges widely, one can weave some overarching themes. 
The chapters fall roughly into three categories, represented by three parts of the volume: macroeconomic interdependence, exchange rates and the first 10 years of Economic and Monetary Union (EMU), and regulatory interventions regarding employment or productivity.

\section{Part I: Macroeconomic Interdependence}

The first three papers concern the continued macroeconomic interdependence of major economies, which is attributable to international capital flows that do not necessarily help stabilize national economies. If we scan today's global economy, "decoupling" is nowhere in sight. Surprising to international economists, interdependence has apparently not been diminished by the free floating of the euro/dollar rate and other major exchange rates.

In "Capital Flow Bonanzas: An Encompassing View of the Past and Present," Carmen M. Reinhart and Vincent R. Reinhart offer an algorithm cataloging capital inflow bonanzas in both advanced and emerging economies during 1980-2007 for 181 countries and 1960-2007 for a subset of 66 economies from all regions. In line with earlier studies, this study shows that global factors-such as commodity prices, international interest rates, and growth in the world's largest economies-have a systematic effect on the global capital flow cycle. Bonanzas are no blessing for either advanced or emerging market economies. In the case of the latter, capital inflow bonanzas are associated with a higher likelihood of economic crises (debt defaults, banking, inflation, and currency crashes). For the advanced economies, the results are not as stark, but bonanzas are associated with more volatile macroeconomic outcomes for GDP growth, inflation, and the external accounts. Possibly relevant for the current situation in such countries as Spain, Ireland, and the United States, the authors also find that lower growth and sustained declines in equity and housing prices follow at the end of the inflow episode.

In "Current Account Sustainability and the Relative Reliability," Stephanie E. Curcuru, Charles P. Thomas, and Francis E. Warnock begin with a survey of some theories that have been offered regarding the sustainability of the U.S. current account deficit. Until now, it has been little noted that the competing theories implicitly rely on competing assertions as to which components of the balance of payments (or of international investment positions) are the most reliable. The authors focus on the data that these theories rely on, provide an evaluation of the relative reliability of data on various subcomponents of the international accounts, and through this analysis weigh in on which theories are better 
supported by the data. Their analysis of the "dark matter" theory from a relative data reliability perspective is straightforward: the theory fails because it is built on the assumption that the most accurate component of the entire set of international accounts is an item that is in fact largely unmeasured (and is, rather, largely inferred from other measures). The authors' analysis of the "exorbitant privilege" theory requires more depth, since they must first construct estimates of adjustments for known shortcomings in the accounts. After plugging various holes in the accounts, they find that the positive returns differential that the United States earns on its net international investment position is much smaller than implied by the exorbitant privilege theory.

As a segue from the second to the third chapter, the editors note that another of the rationales that has been given for the sustainability of the U.S. current account deficit is the hypothesis of a global saving glut and consequent decline in the neutral real interest rate (e.g., by Ben Bernanke, chairman of the U.S. Federal Reserve Board).

"Reflections on Monetary Policy in the Open Economy," by Richard H. Clarida, provides some intuition and quantitative insight into monetary policy choices faced in the open economy. The theoretical sections of the paper focus on three main building blocks: the "open-economy" IS curve, the open-economy Phillips curve, and the open-economy Taylor rule. One result is spillovers from foreign output to the domestic neutral real interest rate and domestic output: potential output in the open economy is not a closed-economy construct and cannot be defined without reference to global developments. Another finding is phrased as a claim that a more open economy will have a flatter Phillips curve. Finally, Clarida finds theoretically and empirically that bad news about inflation will be good news for the exchange rate under a version of inflation targeting. He also introduces a new way to calibrate forward-looking central bank policy rules using financial market data on real interest rates and breakeven inflation rates from inflation-indexed bonds. He applies this approach to the Fed and European Central Bank reaction functions since 2000. According to this analysis, variations in the neutral real interest rate, perhaps caused by the "global saving glut" and enhanced financial integration in a world of inflation-targeting central banks, have played an important role in Fed policy this decade.

\section{Part II: Exchange Rates and the Advent of EMU}

The next two papers concern exchange rate regimes in the context of the coming of EMU in 1999. One of them emphasizes flexible exchange 
rates-the regime that was implicit through much of Part I of the volume-and the other emphasizes firmly fixed exchange rates.

In "Real Variables, Nonlinearity, and European Real Exchange Rates," Mark P. Taylor and Hyeyoen Kim analyze European real exchange rate behavior before and after the implementation of EMU. They model real exchange rates for a number of EMU and non-EMU countries against Germany, and they allow for variation in the equilibrium level of the long-run equilibrium real exchange rate using either relative productivities or real diffusion indexes. Of the five European currencies examined, Switzerland has continuously floated, the United Kingdom has usually floated, Denmark has kept its exchange rate within narrow bands, and France and Austria are typical of the 11 countries that gave up their currencies for the euro in 1999. The estimated models show that real variables are a significant determinant of long-run real exchange rates when incorporated into a nonlinear framework. The researchers also find that the speed of adjustment is generally faster after the implementation of EMU.

The last decade has seen a new area of research: the apparently substantial impact of fixed exchange rates, and especially currency unions, on the direction of trade. In "Exchange Rate Regimes and the Extensive Margin of Trade," Paul R. Bergin and Ching-Yi Lin find that currency unions and direct exchange rate pegs raise trade through distinct channels. Panel data analysis of the period 1973-2000 indicates that currency unions have raised trade predominantly at the extensive margin, the entry of new firms or products. In contrast, direct pegs have worked almost entirely at the intensive margin, increased trade of existing products. The authors develop a stochastic general equilibrium model, featuring price stickiness and firm entry under uncertainty, to understand this result. Because both regimes tend to provide reliable exchange rate stability over the horizon of a year or so, which is the horizon of price setting, both lead to lower export prices and greater demand for exports. But because currency unions historically are more durable than pegs over a longer horizon, they encourage firms to make the longerterm investment needed to enter a new market. The model predicts that whenever exchange rate uncertainty is completely and permanently eliminated, all the adjustment in trade occurs at the extensive margin.

Firm-level analysis is a new fertile area of research that straddles the borders between open-economy macroeconomics, trade theory, and industrial organization. The Bergin-Lin paper's use of firm-level data provides a nice segue to the next paper. 


\section{Part III: Regulatory Interventions Regarding Employment or Productivity}

The final two papers lie at the intersection of microeconomics and macroeconomics. Productivity and employment are two of the most important macroeconomic variables; after all, the two together determine national output. But productivity and employment are both influenced by various microeconomic interventions on the part of the government-especially in continental Europe, where regulation is often greater than in the United States.

In "Plant Size Distribution and Cross-Country Income Differences," Laura Alfaro, Andrew Charlton, and Fabio Kanczuk use firm-level data for 79 developed and developing countries to investigate whether differences in the allocation of resources across plants that are heterogeneous in size are a significant determinant of cross-country differences in income per worker across countries. The researchers use a standard version of the neoclassical growth model augmented to incorporate monopolistic competition among heterogeneous firms. For their preferred calibration, the model explains $58 \%$ of the log variance of income per worker across countries, as compared to the $42 \%$ success rate of the usual model. The editors emphasize that the paper is predicated on the assumption that the broad question of whether the allocation of resources across plants is efficient can be captured by the narrow dimension of the size distribution of plants.

In "Regional Difference-in-Differences in France Using the German Annexation of Alsace-Moselle in 1870-1918," Matthieu Chemin and Etienne Wasmer show how to shed light on three questions of labor policy by looking at the "treatment effect" of an "experiment." The experiment concerns the region of Alsace-Moselle, its acquisition of different labor market institutions when under the control of Germany (1870-1918), the way Alsace-Moselle was returned to France in 1918, and the persistence to this day of some differences in these institutions. The three policy experiments are (1) a slightly less stringent reduction in working time in AlsaceMoselle when the rest of France went to a 35-hour workweek 10 years ago, (2) more generous policies regarding absenteeism/sick leave in this region, and (3) more generous welfare assistance for impoverished citizens. Even a simple application of the difference-in-differences methodology can shed some light on the effects of these policies on employment and unemployment. Perhaps the authors' most important result is a finding of no significant difference in employment from the rest of France when the 35-hour workweek was implemented in 1998-2000, which casts serious doubt on the effectiveness of this regulation at its intended goal of raising employment. 
